\title{
Alan I. Taub Receives 2000 Woody Award
}

Alan I. Taub, executive director of science in the Research and Development Department of General Motors, is the recipient of the 2000 Materials Research Society Woody Award. Harry A. Atwater, 2000 MRS President, made the presentation to Taub at the MRS Fall Meeting in Boston in November.

The Woody Award recognizes outstanding service and dedication to MRS as exemplified by its namesake, Woody White, 1984 MRS President. The award is bestowed annually by the MRS president to an individual for extraordinary contributions to the Society.

"Alan bleeds MRS-blue blood," Atwater said while presenting the award. "He took us to a new place of stability and durability."

Taub served on Council from 1995 to 2000, including two consecutive terms as liaison to the Executive Committee. He co-chaired the 1993 MRS Fall Meeting, and co-organized four symposia prior to that. He has been active on various committees, including Awards, Long-Range Planning, Program, and Public Affairs. He led the MRS Headquarters Building

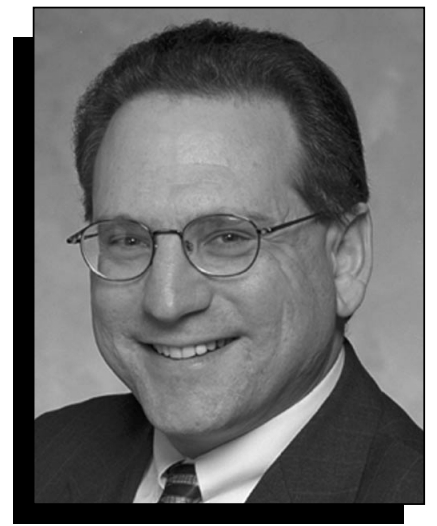

Alan I. Taub

Task Force and served on the Financial Group and the headquarters Salary Task Force. He currently chairs the Materials MicroWorld Fundraising Task Force.

Merrilea J. Mayo, Treasurer of MRS, has worked with Taub on many projects. She said, "Alan moves committees effortlessly along the route from concept to final project. On time, on budget, on the mark. He is the quintessential 'good guy': You wish you could be jealous of him, because of his impressive list of outstanding accomplishments, but you simply can't, because he is just great to be around."

Taub has recently moved to GM from Ford Motor Co. where he managed the Vehicle Crash Safety Engineering Department and the Scientific Research Laboratory before that. His research interests have included studies in flow and structural relaxation of amorphous alloys for electric power transformers, mechanical properties of rapidly solidified nickel-based alloys with emphasis on improved ductility in intermetallic compounds for hightemperature turbine applications, and processing of superconducting materials for high-field medical magnets. Taub received his PhD degree in applied physics at Harvard University in 1979. He has been honored with the ASM Morris Cohen Award for Materials Science (1975) and the Alfred Geisler Award for a Young Metallurgist (1987), and he serves on the advisory board of the Materials Science Departments of Harvard, Brown University, and the Massachusetts Institute of Technology. Taub is the author of over 60 technical publications and 26 patents. 